\title{
FIGUR NARATIF DALAM SENI PATUNG
}

Oleh: Asep Prasetyo

Institusi: Institut Seni Indonesia Yogyakarta

\begin{abstract}
ABSTRAK
Tema yang diangkat adalah tentang figur naratif yang divisualisasikan melalui karya seni tiga dimensi. Kecintaan seniman terhadap mainan anak dan pengaruh siaran televisi berdampak pada penciptaan karya.

Aktifitas mengumpulkan mainan dan menonton film animasi merupakan suatu kesenangan tersendiri bagi seniman yang secara tidak sadar telah memengaruhi seniman dalam berbuat atau pun membuat karya seni yang dilakukan selama ini. Begitu juga dengan cerita dari sebuah film, juga dijadikan sebagai konsep dalam berkarya.

Sebuah cerita naratif juga dijadikan sebagai konsep atas perwujudan karya, seperti halnya dalam komik, penikmat dapat langsung menangkap pesan yang masuk di dalamnya, karena adanya teks yang memperkuat gambar. Dalam pembuatan karya seniman mencoba menghadirkan cerita naratif dalam wujud karya tiga dimensi.

Dalam perwujudan karya yang menempatkan cerita sebagai landasan awal dalam membuat bentuk, didapati sebuah realitas baru saat proses pengerjaan karya dengan teknik dan material. Teknik yang dipakai seniman yang mayoritas menggunakan material dari barang temuan menyebabkan cerita tidak dapat diwujudkan secara terperinci dan detail seperti halnya pada komik ataupun pada novel grafis.
\end{abstract}

Kata kunci: figur, naratif, cerita, kumpulan

\section{ABSTRACT}

The theme is about the narrative figure that is visualized through a threedimensional artwork. Love the author of the toys and the influence of television broadcasts have an impact on the creation of the work.

Activity collecting toys and watched the animated movie is a pleasure for authors who unknowingly have influenced the author in doing or even create artwork done so far. So is the story of a film, is also used as a concept in the work.

A narrative story was also used as a concept on the embodiment of the works, as well as in the comics, the lovers can instantly capture incoming messages in them, because of the text that reinforces the image. In the making of the work in this thesis the author tries to present a narrative story in the form of three-dimensional works.

In the embodiment works that put the story as an initial basis in making shapes, found a new reality when the process works with the techniques and materials used. Teknik majority writer uses material from artifacts caused story can not be realized in detail and detail as well as in comic or on the graphic novel.

Keywords: figure, narrative, story, assemblage 


\section{PENDAHULUAN}

Setiap orang pasti mempunyai kesukaannya masing-masing, dan tentu tidak sama antara satu dengan yang lain, baik dalam usia anak-anak maupun dewasa. Selain sebagai kegiatan pemuas batiniah, banyak juga di era saat ini kesukaan akan berbagai hal dapat diaplikasikan menjadi sebuah hobi, yang selanjutnya dapat menjadi kegiatan yang dapat menopang dalam mencukupi kebutuhan hidup, salah satunya adalah kegiatan mengoleksi. Mengoleksi merupakan kegiatan mengumpulkan suatu barang yang dianggap bernilai bagi orang yang mengumpulkanya, contohnya mengoleksi buku, mainan, majalah, barang antik, barang remeh-temeh dan sebagainya.

\section{A. Latar Belakang Penciptaan}

Aktifitas mengumpulkan mainan dan menonton film animasi merupakan suatu kesenangan tersendiri bagi seniman yang secara tidak sadar berpengaruh pada keseharian dan proses berkarya seniman selama ini. Seperti yang diungkapkan oleh M. Dwi Marianto (2010, hal. 6) dalam pengantar pameran In Repair menjelaskan bahwa:

Kita adalah apa yang kita perhatikan, alami dan lakukan setiap hari. Yang paling kita dengar, baca, obrolkan dan mainkan, dengan sendirinya membentuk pola pandang, pemetaan persepsi dan mimpi-mimpi kita. Semua itu niscaya terekam di otak. Maka wajarlah apabila dari media dan game-game yang kita tonton secara langsung maupun tidak mempengaruhi cara dan bahasa kita dalam meyatakan sesuatu yang bersifat pribadi.

Mencipta karya seni adalah pengungkapan pernyataan yang bersifat pribadi. Tujuan utamanya bukan untuk pemenuhan kebutuhan pokok, melainkan suatu usaha untuk memenuhi kebutuhan yang bersifat spiritual.

Hal-hal yang menjadi kesenangan bagi seniman merupakan modal dasar dalam proses berkarya selanjutnya. Mengerjakan sesuatu yang disenangi juga akan membawa perasaan yang senang bagi orang yang mengerjakanya,seperti halnya bekerja tanpa ada beban.Berawal dari figur-figur karakter mainan dan filmfilm animasi muncul sebuah motivasi untuk menciptakan sebuah figur yang belum pernah ada dan tentu saja sebuah cerita yang akan mengiringi figur ciptaan tersebut. Berbeda dengan penyajian atas cerita pada film animasi dengan format 
audio visual menggunakan perantara media teknologi atau cerita bergambar yang menggunakan media dua dimensi, untuk kali ini seniman mencoba mengoptimalkan semua benda kesenangan seniman melalui media tiga dimensi.

\section{B. Rumusan Penciptaan}

Bagaimana visualisasi yang terwujud atas cerita naratif beserta figur dengan pemanfaatan benda temuan, apabila diangkat ke dalam karya seni rupa tiga dimensi, yaitu seni patung?

\section{Teori dan Metode \\ Teori}

Karya seni merupakan media ungkap bagi seniman yang membuatnya, biasanya karya seni mengandung muatan atau konsep yang menjadi alasan bagi seniman mengenai inti atau makna yang terkandung di dalamnya. Konsep tersebut dapat berupa ungkapan perasaan, kondisi sosial masyarakat, politik,sebatas eksplorasi material dan lain sebagainya.

Dalam Kamus Lengkap Bahasa Indonesia, cerita diartikan sebagai,“ Tuturan yang membentangkan bagaimana sesuatu terjadi, peristiwa, hal atau kejadian dan sebagainya; karangan yang mengisahkan perbuatan, pengalaman, penderitaan orang dan sebagainya"(Tri Rama, hal. 112). Melalui pengertian tersebut, makna cerita didapati semakin meluas. Cerita tidak hanya ada pada legenda, dongeng atau cerita rakyat yang telah turuntemurun dan memaparkan atau mengkomunikasikan sebuah kisah, pengalaman, peristiwa dari lisan ke lisan juga dapat diartikan sebagai aktifitas bercerita. Dalam cerita terdapat unsur-unsur pembangunya seperti tema, tokoh, setting atau latar.

Sebuah cerita naratif juga dapat dijadikan sebagai konsep atas perwujudan karya, seperti halnya dalam komik. Dalam komik penikmat dapat langsung menangkap pesan yang masuk di dalamnya, karena adanya teks yang memperkuat gambar. Dalam pembuatan karya seniman mencoba menghadirkan cerita naratif dalam wujud karya tiga dimensi.

Lingkungan sekitar yang dirasakan seniman selama kuliah turut serta mendukung seniman dalam menciptakan karya, berdasarkan pengalaman 
ketika sangat suka menonton sebuah berbagai film kartun kemudian ketertarikan seniman pada alur cerita dan tokoh-tokoh yang disajikan menjadikan keinginan seniman untuk membuat cerita dan tokoh-tokoh ke dalam wujud seni patung.

Karena didasari dengan unsur cerita yang selanjutnya diwujudkan dalam karya tiga dimensi maka seniman mengedepankan unsur cerita, yaitu tokoh dan setting atau latar. Untuk tokoh, seniman menggunakan berbagai macam figur-figur. Gadis berkacamata sebagai figur utama, dan juga figurfigur yang lain dengan menggunakan teknik yang beragam dalam pembuatanya. Teknik modelling, ready made dan assemblage adalah teknik yang digunakan dalam penciptaan tokoh.

\section{Metode}

Lingkungan sekitar yang dirasakan seniman selama kuliah turut serta mendukung seniman dalam menciptakan karya, berdasarkan pengalaman ketika sangat suka menonton sebuah film-film kartun kemudian ketertarikan seniman pada alur cerita dan tokoh-tokoh yang disajikan memperkuat keinginan seniman untuk membuat cerita dan tokoh-tokoh ke dalam wujud seni patung .

Karena didasari dengan unsur cerita yang selanjutnya diwujudkan dalam karya tiga dimensi maka seniman mengedepankan unsur cerita, yaitu tokoh dan setting atau latar. Untuk tokoh, seniman menggunakan berbagai macam figur-figur. Gadis berkacamata sebagai figur utama, dan juga figurfigur yang lain dengan menggunakan teknik yang beragam dalam pembuatanya. Teknik modelling, ready made dan assemblage adalah teknik yang digunakan dalam penciptaan tokoh.

Dalam proses perwujudan karya yang menempatkan cerita sebagai landasan awal dalam membuat bentuk, didapati sebuah realitas baru saat proses pengerjaan karya dengan teknik dan material .Teknik yang dipakai seniman yang mayoritas menggunakan material dari barang temuan menyebabkan cerita tidak dapat diwujudkan secara terperinci dan detail seperti halnya pada komik ataupun pada novel grafis. Berdasarkan permasalahan ini, bentuk dari karya yang terlihat tidak memiliki keterkaitan 
antara visual dengan cerita. Seniman lebih mengutamakan esensi dari cerita atau hanya menangkap inti cerita saja.

\section{HASIL DAN PEMBAHASAN KARYA}

Komik, Ilustrasi, Novel Grafis adalah beberapa macam cerita yang mengedepankan unsur visual berupa gambar di atas media dua dimensi. Melalui kesenangan seniman dalam mengumpulkan mainan, maka seniman hendak memvisualisasikan cerita dengan memanfaatkan mainan dan benda-benda temuan tersebut. Berbagai problem realitas muncul pada saat proses pengerjaan yang menjadikan proses perwujudanya sangat berbeda dengan gambaran di awal. Adapun wujud yang tercipta sebagai berikut :

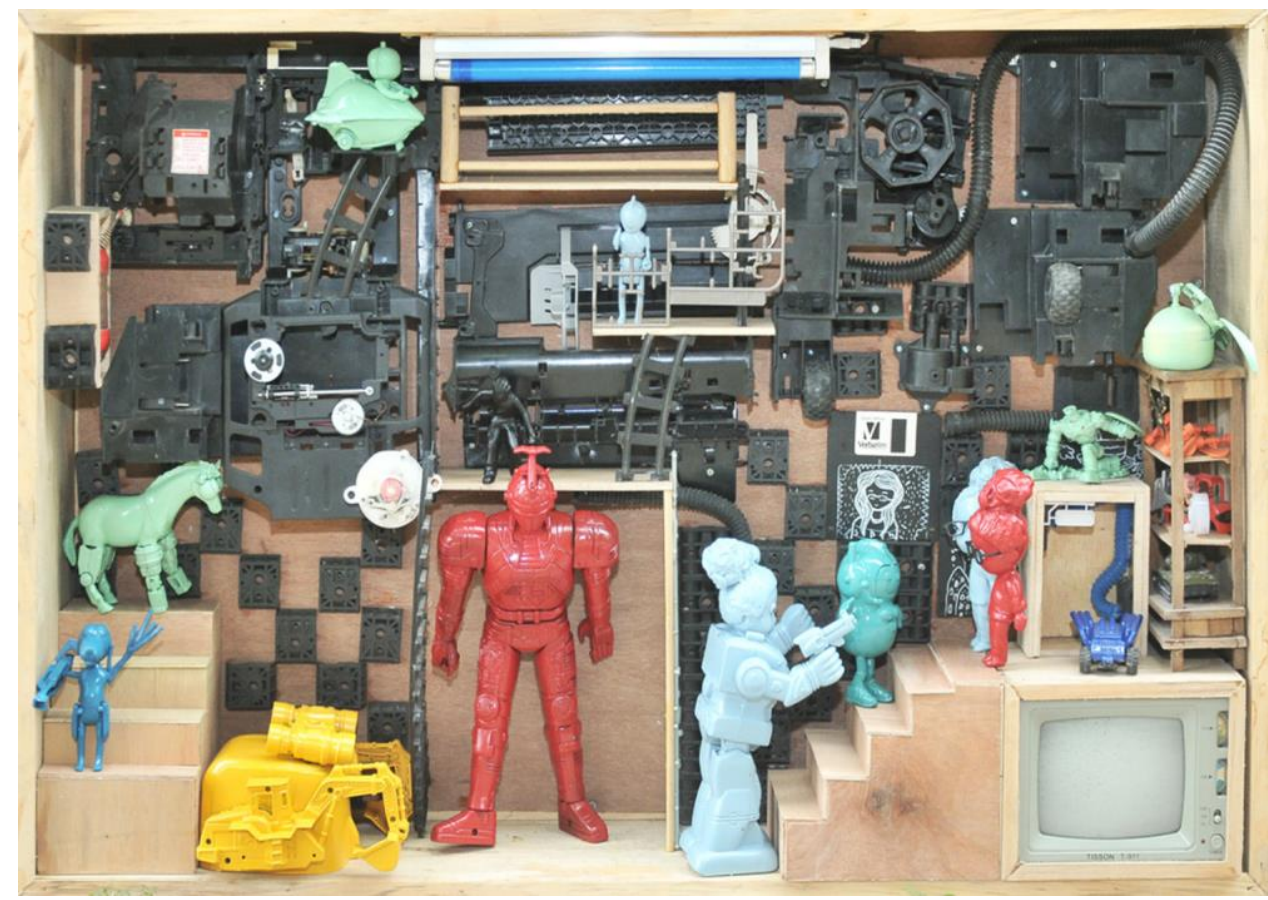

Gambar 1.

Asep Prasetyo, Galaksi Luas, 2015

Polyester resin, kayu , mainan plastik, rumput sintetis, sintetic clay, lampu neon spray paint $92 \times 16 \times 62 \mathrm{~cm}$

(Foto: Asep Prasetyo)

Dalam karya Galaksi yang Luas digambarkan sebuah lingkungan yang berbeda dari penampakan lingkungan sehari-hari, seakan berada di galaksi lain yang dipenuhi dengan teknologi canggih. Berbagai benda-benda bekas dari komponen alat elektronika dan cashing beberapa mainan menandakan kesan adanya kemajuan teknologi dalam karya ini. Beberapa figur dengan beragam 
teknik menjadi komponen dalam karya ini. Figur wanita dengan badan robot menandakan warga dari galaksi tersebut. Berbagai figur-figur lainya juga merupakan penghuni dari tempat itu. Sebuah robot warna merah menandakan akan kemajuan teknologi, yang dibuat dengan teknik custome yang hanya mengalami pengubahan pada warna. Pemanfaatan barang jadi terletak pada penggunaan televisi yang disajikan apa adanya tanpa mengalami pengubahan sedikitpun sehingga menguatkan kesan teknologinya.

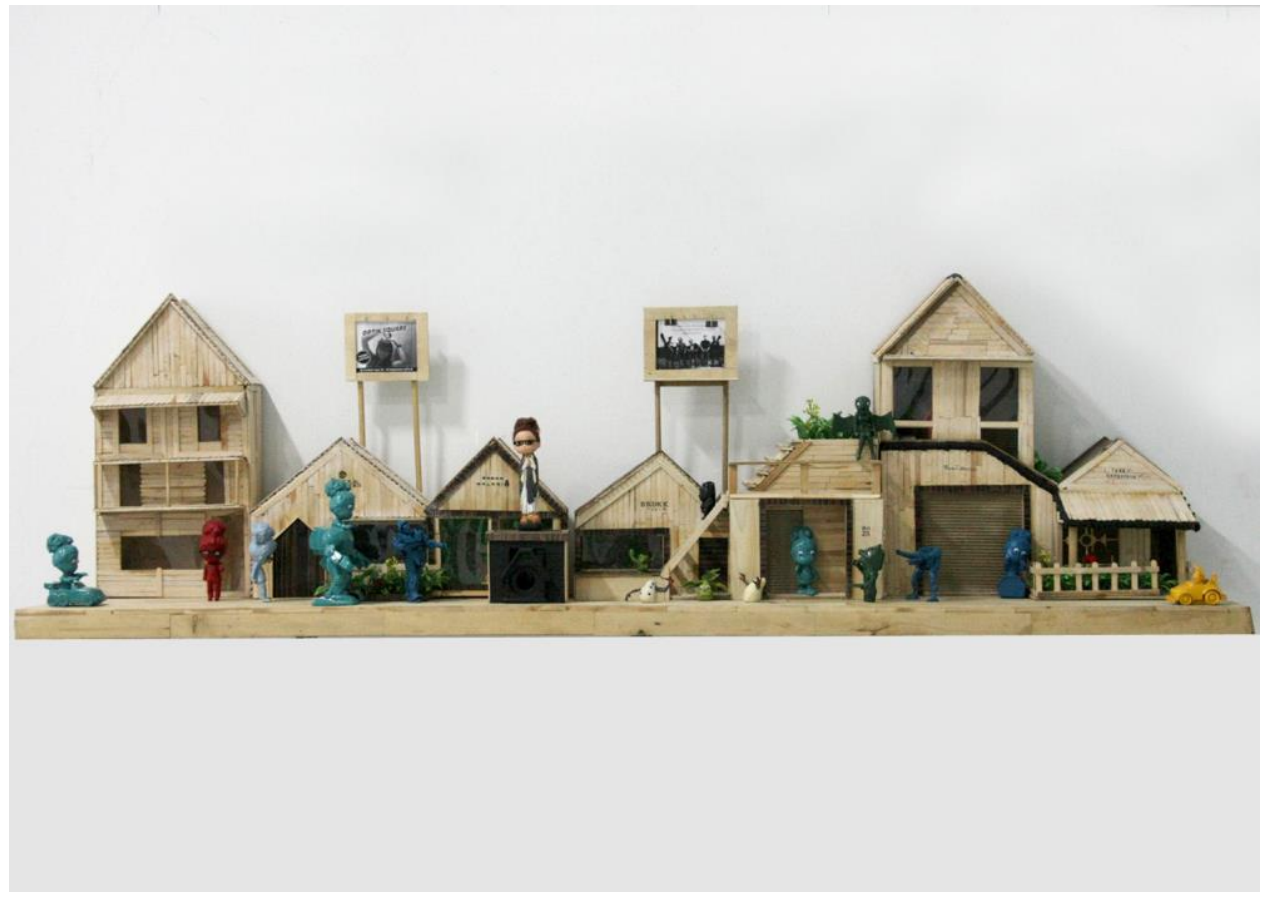

Gambar 2.

Asep Prasetyo, Jumpa Kota ,2015

Polyester resin, kayu , mainan plastik, rumput sintetis, sintetic clay,spray paint $200 \times 42 \times 65 \mathrm{~cm}$

(Foto; Asep Prasetyo)

Bangunan-bangunan yang berupa rumah kayu dengan dilengkapi tanaman dari rumput synthetic beserta baliho-baliho yang menjulang menandakan suasana perkotaan. Berbagai figur penduduk kota yang beragam bentuknya memadati kota tersebut. Figur wanita berada dalam kota tersebut bersama dengan teman-teman baru mereka. Suasana kerohanian nampak karena dengan adanya sosok figur Bunda Maria yang menjadi landmark kota tersebut. Namun, dibalik suasana rohani, hening dan damai tersebut tersimpan sesuatu yang mencekam. Suasana mencekam ini disimbolkan dengan adanya makhluk-makhluk ganjil yang selalu 
mengawasi dan beberapa di antaranya bersenjata. Figur wanita hanya memilih diam menutup diri dari lingkungan sekitar.

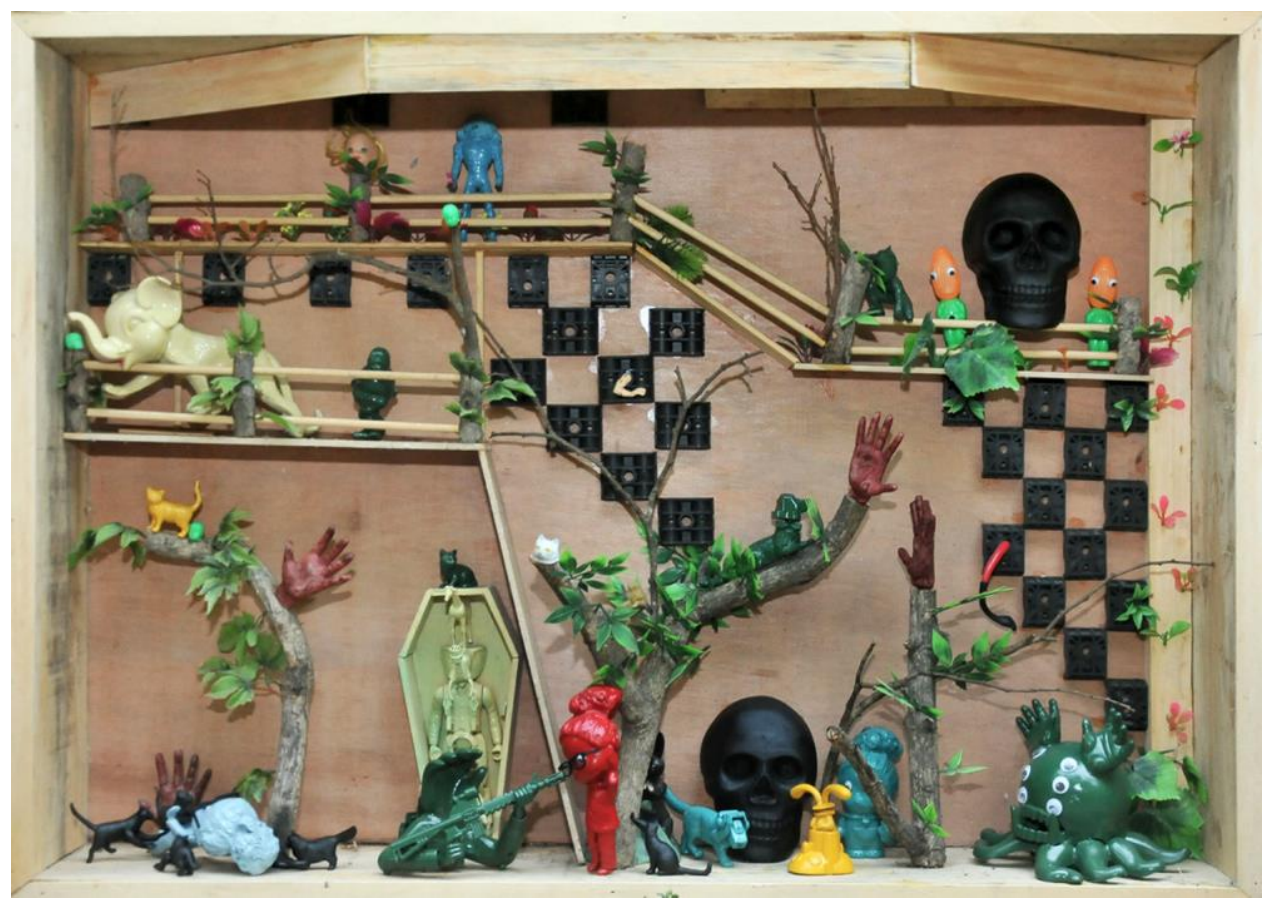

Gambar 3.

Asep Prasetyo, Pulau Kucing, 2015

Polyester resin, kayu, mainan plastik, rumput sintetis, sintetic clay, lampu neon, spray paint $92 \times 16 \times 64 \mathrm{~cm}$

(Foto: Asep Prasetyo)

Suasana hutan telah menjadi kerajaan binatang. Berbagai binatang yang aneh menempati dan menguasai daerah tersebut. Berbagai ranting pohon menandakan pepohonan yang menandakan lebatnya hutan. berbagai hewan aneh dari gabungan mainan plastik mendominasi dalam karya ini. Petualangan dari figur wanita berlanjut ke dalam hutan ini. Kejadian-kejadian yang tidak diinginkan sepenuhnya terjadi tempat ini. Salah satu dari figur wanita harus menghembuskan nafas terakhir karena dimangsa oleh sekelompok kucing. Sedangkan figur wanita yang lain menjadi tawanan oleh makhluk aneh bersenjata. Beberapa tangan yang muncul dari pohon menandakan banyaknya korban yang telah berjatuhan di dalam hutan ini. Sedangkan tengkorak berwarna hitam adalah tanda akan bahaya dan kematian. 


\section{SIMPULAN}

Bermodal berbagai material yang ada di sekitar dan berbagai mainan koleksi seniman yang sekiranya dapat dijadikan material utama dalam seni patung, seniman mengeksekusi material-material tersebut untuk selanjutnya dijadikan menjadi karya yang mengandung unsur cerita. Material tersebut diwujudkan menjadi tokoh dan elemen setting.

Karena proses penciptaan karya yang berangkat dari sebuah cerita, maka pada proses perwujudan karyapun ditemukan realitas yang berbeda. Hal ini disebabkan karena adanya batasan dari material yang digunakan, yaitu proses visualisasi cerita yang dihadapkan dengan material yang berupa benda-benda temuan. Sebagai hasil dari proses perwujudan karya, seniman hanya menangkap esensi dari cerita. Material yang digunakan tidak dapat digunakan sepenuhnya sebagai perwujudan ungkapan gagasan cerita. Realitas tersebut menimbulkan kebebasan interpretasi bagi penikmat karya, sehingga akan membuka pintu interpretasi selebar-lebarnya dan karya akan menjadi lebih kaya dan bernilai.

\section{DAFTAR PUSTAKA}

M. Dwi Marianto, "Toys from earth" katalogus pameran In Repair pameran Seni Rupa Srisasanti syndicate, Bentara Budaya Yogyakarta 03 12 Des, 2010.

Rama, Tri, Kamus Lengkap Bahasa Indonesia, Karya Agung, Surabaya. 